\title{
The influence of moisture on the permeability of crushed shale samples
}

\author{
Mercy Achang ${ }^{1} \cdot$ Jack C. Pashin ${ }^{1} \cdot$ Eliot A. Atekwana ${ }^{2}$
}

Received: 2 February 2018 / Published online: 3 June 2019

(c) The Author(s) 2019

\begin{abstract}
Shale cuttings and cores recovered from the subsurface and stored for hours to decades tend to dry out and lose moisture and hydrocarbons, leading to an increase in the effective matrix permeability. Moisture loss in shale samples is a fundamental sample preservation problem which can be solved by applying a standard moisture equilibration procedure to restore lost moisture. Our aim was to investigate the relationship between permeability and variable moisture as-received, as-received moisture-equilibrated and saturated moisture-equilibrated samples. Samples were crushed to a series of particle sizes (0.62.0) $\mathrm{mm}$ and moisture equilibrated at $97 \%$ relative humidity. Results show that moisture equilibration in the samples was achieved after $72 \mathrm{~h}$. The permeability of the saturated moisture-equilibrated and as-received moisture-equilibrated samples decreased exponentially with increase in moisture content. The high correlation coefficient between permeability and particle size ( $r=0.96$ and 0.97$)$ for moisture-equilibrated samples compared to 0.76 for as-received samples indicates that moisture equilibration improves permeability measurements in crushed shale samples. Furthermore, permeability measurements are repeatable for moisture-equilibrated samples compared to samples that were not equilibrated (as-received). We conclude that moisture content affects permeability and moisture equilibration normalizes and improves the repeatability of permeability measurements in crushed shale.
\end{abstract}

Keywords Crushed shale $\cdot$ Matrix permeability $\cdot$ Moisture equilibration

\section{Introduction}

Shale is a fissile mudrock composed of clay minerals, carbonate, silica, and organic matter (Ingram 1953; Loucks et al. 2012). When shale cuttings and cores are recovered from the subsurface and stored, they tend to dry out, and measurable changes in moisture content may occur in a matter of hours and continue for decades (Clarkson et al. 2011). The loss of moisture and hydrocarbons increases the effective permeability of stored shale samples and induces capillary artifacts that affect permeability measurements (Chenevert et al. 1997). For example, Clarkson et al. 2011

\section{Edited by Jie Hao}

Mercy Achang

mercy.achang@okstate.edu

1 Boone Pickens School of Geology, Oklahoma State University, Stillwater, OK 74078, USA

2 Department of Geological Sciences, University of Delaware, Newark, DE 19716, USA determined that the fluid saturation of crushed shale samples can decrease from $40 \%$ to $2 \%$ in less than $12 \mathrm{~h}$ at $20{ }^{\circ} \mathrm{C}$. Clarkson et al. (2011) showed that the rate of dehydration in shale is faster in crushed samples and cuttings than in whole cores and suggested the need to use preserved samples that have not lost moisture (e.g., preserved in polythene bags or dipped in wax) to determine petrophysical properties of stored samples. Most laboratories store cores in polythene bags to minimize dehydration. However, the cores and cuttings still dehydrate over time since the temperature and sample stress conditions during storage differ from those in the subsurface.

Moisture conditioning is a common procedure for the proximate analysis of coal (ASTM 1412), which is prone to moisture loss following sampling, especially in lignite and subbituminous coals. Moisture equilibration or conditioning is the process by which hygroscopic materials reach equilibrium with the ambient relative humidity of the air by absorbing or desorbing moisture until the material neither loses nor gains moisture from the environment. For example, coal and shale naturally contain water and are susceptible to 
moisture loss. Moisture equilibration can be performed rapidly on crushed shale samples, but is difficult, if not impossible for core plugs or even cuttings, where conditioning would require equilibration times on the order of months to years. Even then, the rock may still not reach equilibrium moisture at ambient temperature and pressure. According to the ASTM (D1412-07) standard method for coal moisture equilibration, samples are to be saturated (wet) before equilibration. However, for coal samples that deteriorate when treated with water, it is recommended that they are equilibrated directly without wetting, provided the samples were collected and prepared with minimal loss of moisture (ASTM, D1412-07). Chenevert et al. (1997) have shown that moisture in shale should be preserved at native or bed moisture values to accurately measure physical properties (e.g., saturation, porosity, permeability, and bulk volume). However, no investigations have been performed to systematically determine the relationship between moisture content and matrix permeability in shale. Moisture loss in shale is a sample preservation problem that calls for a standard procedure to restore moisture in cores and cuttings before permeability measurements are made. If a shale sample contains expandable clay, the inherent moisture content will influence clay volume, pore volume, and permeability. Expandable clays when moisturized increase in volume and will reduce pore volume and the size of pore throats, thus decreasing porosity and permeability (Morris and Shepperd 1982).

One way to investigate the effect of moisture in preserved shale samples is to measure the permeability of the samples as received and at different moisture contents. Moisture content can be varied by oven-drying a water-saturated sample for different time periods. The effect of moisture equilibration on permeability can be established by comparing the permeability of as-received samples and moisture-equilibrated samples. The objective of this study was to perform controlled experiments to evaluate the relationship between moisture content and matrix permeability in as-received shale samples and moisture-equilibrated shale samples across a range of different crushed particle sizes. To accomplish this, we used the standard methods for moisture equilibration of coal (ASTM, D1412-07) and measured shale permeability by analyzing the pressure decay curves obtained from the Shale Matrix Permeameter (Core Laboratories SMP 200) (Achang et al. 2017).

\section{Materials and methods}

\subsection{Workflow for sample analyses}

The core that was used for this study is from the Danker \#1-28 well (API number 350812381700003), which was recovered from the Woodford Shale (Devonian) in Lincoln
County, Oklahoma, USA, and was donated to the Boone Pickens School of Geology by Sundown Energy. A description and graphic log of the core are available in Achang et al. (2017). The mineralogy consists of quartz and orthoclase (potassium feldspar) ranging from $44 \%$ to $72 \%$, clay $10 \%$ to $22 \%$, calcite $1 \%$ to $3 \%$, dolomite $7 \%$ to $24 \%$, and pyrite and marcasite $3 \%$ to $37 \%$ in the $14 \mathrm{ft}(4.4 \mathrm{~m})$. Also, the shale contains chlorite, illite, and kaolinite which are non-expandable, including minimal quantities of expandable clay and is thus minimally reactive with water. Samples from the core were taken from depths of 4907-4909 ft (1495.7-1496.3 m) and 4909-4911 ft (1496.3-1496.9 m) and crushed with a hammer on a metal slab and sieved to particles sizes of 2.0, $1.7,1.4,1.2,1.0,0.85,0.71$, and $0.60 \mathrm{~mm}$. The as-received samples used in this research are the same as those used in Achang et al. (2017). The workflow for the procedure used in this study is shown in Fig. 1. A Core Laboratories Shale Matrix Permeameter (SMP 200) was used for measurement of pressure decay curves resulting from helium entering the sample. The pressure decay curves were used to estimate permeability using the methods described by Cui et al. (2009) and Achang et al. (2017).

\subsection{Moisture equilibration of as-received samples}

The moisture equilibration process is detailed in ASTM Standard D1412-07 and begins with vacuum saturating crushed samples with water as shown (Fig. 1a, b) in steps 1 and 2. Five duplicate samples weighing $20 \mathrm{~g}$ with a particle size of $1.4 \mathrm{~mm}$ were placed in a conical flask, and $100 \mathrm{ml}$ of deionized water $(18.2 \mathrm{M} \Omega \mathrm{cm})$ was added to wet the samples. The sample in the conical flask was placed in a desiccator for $3 \mathrm{~h}$ at a pressure of $1.2 \mathrm{MPa}(170 \mathrm{psig})$ and a temperature of $23{ }^{\circ} \mathrm{C}$. Next, the sample was transferred into a Büchner-type funnel and the water was drained. A balance (Mettler Toledo) was used to determine the weight of a 90-mm-diameter Pyrex glass Petri dish. The samples were transferred to the Petri dish, and the weights of the saturated (wet) sample and the Petri dish were recorded. The weight of the sample was estimated to be $15 \mathrm{~g}$ by subtracting the mass of the Petri dish from the combined mass of the sample and the Petri dish. The 15-g sample in the Petri dish was placed in a vacuum desiccator containing saturated potassium sulfate to maintain a relative humidity $(\mathrm{RH})$ at $97 \%$ and a pressure of $30 \mathrm{mmHg}(0.58 \mathrm{psig}$ or $4 \mathrm{kPa})$ in the vacuum desiccator. The desiccator and its contents were placed in an isotherm water bath at a temperature of $30{ }^{\circ} \mathrm{C}$ (required temperature for moisture equilibration at a relative humidity of $97 \%$ ) for moisture equilibration. One sample was withdrawn from the desiccator every $24 \mathrm{~h}$, the weight measured, then dried in an oven at $105{ }^{\circ} \mathrm{C}$ until constant weight. It took about $1.5 \mathrm{~h}$ for constant weight to be attained; the duration of $1.5 \mathrm{~h}$ was established by drying a sample at 

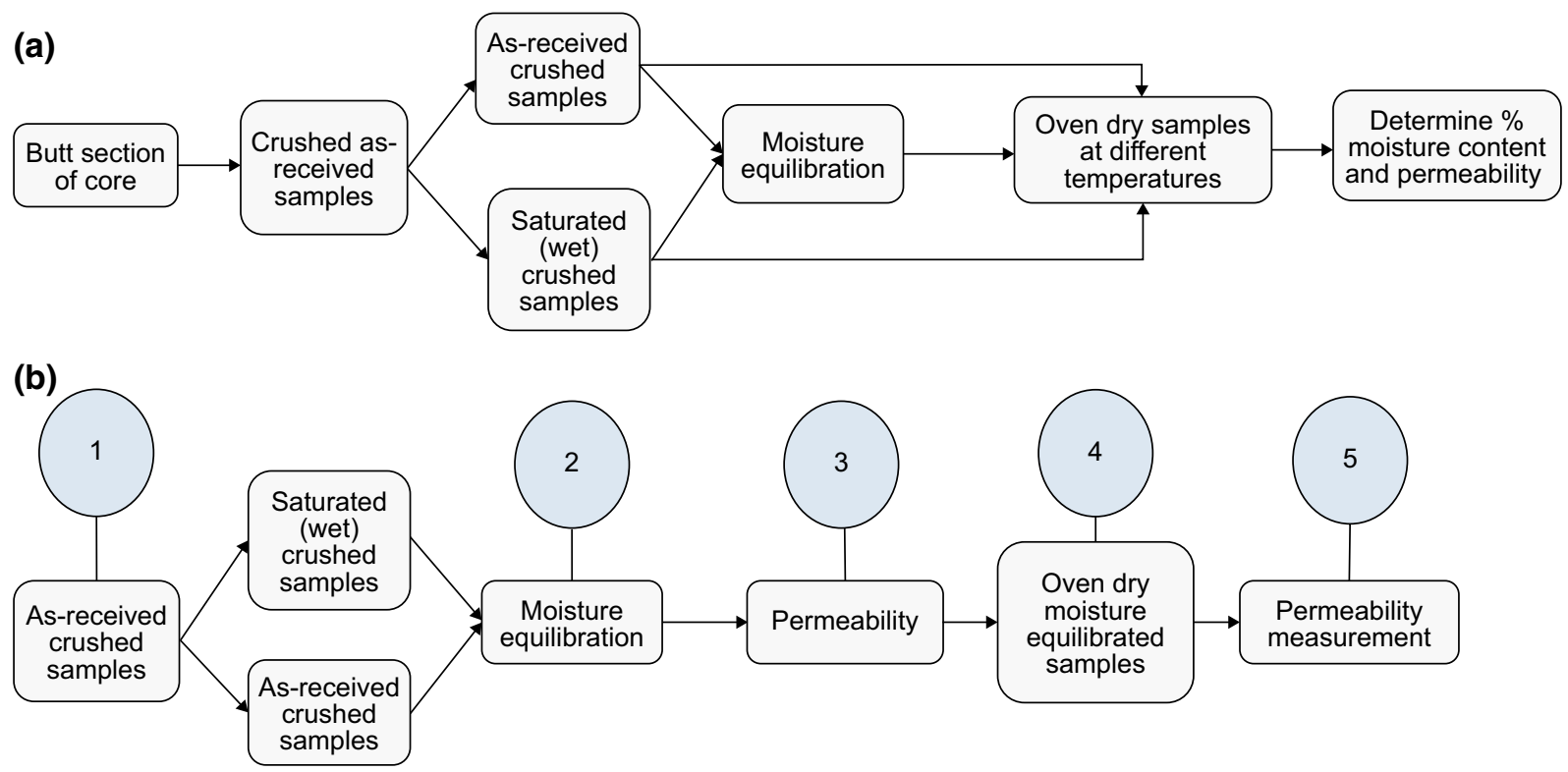

Fig. 1 Schematic of the procedure for a permeability determination at different moisture contents and $\mathbf{b}$ moisture equilibration and permeability determination. Numbers $1-5$ indicate the major steps in the workflow

0.5-h intervals and determining when the weight of the sample became constant. After drying, the Petri dish containing the sample was removed from the oven, cooled for $0.5 \mathrm{~h}$ in a desiccator, and weighed. The weight was recorded, and the percent equilibrium moisture content was calculated.

Equilibrium moisture $(\%)=\left(\frac{B-C}{B-A}\right) \times 100$

where $A=$ weight of the Petri dish, $B=$ weight of Petri dish and wet shale, and $C=$ weight of the Petri dish and dried shale in grams. The moisture equilibration procedure described above was used for all the samples saturated with water before equilibration (saturated moisture equilibrated), and the wetting step was skipped for samples moisture equilibrated without wetting (as-received moisture equilibrated). Depths associated with data are for identification purposes only

\subsubsection{Length of moisture equilibration}

To determine how long as-received samples and wet saturated samples should be moisture equilibrated, three sets of five samples of $15 \mathrm{~g}$ each and $1.4 \mathrm{~mm}$ particles were used. Five samples were saturated with water for $3 \mathrm{~h}$ and another five samples for $24 \mathrm{~h}$, respectively. The remaining five samples were kept in the as-received (stored) state. All the samples were moisture equilibrated as described above by placing them in a desiccator containing saturated potassium sulfate at a pressure of $30 \mathrm{mmHg}(0.58$ psig or $4 \mathrm{kPa})$. The desiccator was then placed in a water bath regulated at $30{ }^{\circ} \mathrm{C}$. One sample was withdrawn after $24 \mathrm{~h}, 48 \mathrm{~h}, 72 \mathrm{~h}$,
$96 \mathrm{~h}$, and $120 \mathrm{~h}$, weighed and oven-dried to a constant weight. The weights were used to determine the moisture equilibration behavior for the water-saturated samples and for the as-received (unsaturated) moisture-equilibrated samples.

\subsection{Variation in moisture content and permeability}

To estimate the initial moisture content of the $15 \mathrm{~g}$ sample of crushed shale (particle size $=1.4 \mathrm{~mm}$ ) obtained from a depth of 4909-4911 ft (1636-1637 m), the sample was ovendried at $105{ }^{\circ} \mathrm{C}$ for $1.5 \mathrm{~h}$, then cooled in a desiccator, and the weight measured. The difference in the weights was equivalent to the mass of the initial moisture content which was converted into percent $(\%)$ pore volume. To determine the relationship between moisture content and permeability, the moisture content in the sample was varied by oven-drying for $1.4 \mathrm{~h}$ at 20 -min intervals. Figure $1 \mathrm{a}$ shows a flowchart of the procedure followed for moisture content-permeability experiments.

A mass of $80 \mathrm{~g}$ (particle size $=1.4 \mathrm{~mm}$ ) of crushed shale was vacuum saturated with DI water at $23{ }^{\circ} \mathrm{C}$ for $3 \mathrm{~h}$. The sample was placed in an oven at an initial temperature of $40{ }^{\circ} \mathrm{C}$ for $20 \mathrm{~min}$, then removed and cooled in a desiccator for $0.5 \mathrm{~h}$, and the permeability measured. The moisture content of the sample was estimated from the weight differences. The temperature of the oven was increased by $20{ }^{\circ} \mathrm{C}$, and the sample was placed again in the oven for $20 \mathrm{~min}$, removed and cooled, and moisture content estimated and permeability measured. This drying step was repeated for 20-min increments to $120^{\circ} \mathrm{C}$. Also, the as-received sample 
was moisture equilibrated and the moisture content and permeability measured as described above.

\subsection{Permeability measurements of as-received samples, as-received moisture-equilibrated samples, and saturated moisture-equilibrated samples}

The pressure decay curves of $75-80 \mathrm{~g}$ of each particle size $(0.6 \mathrm{~mm}, 0.7 \mathrm{~mm}, 0.85 \mathrm{~mm}, 1.0 \mathrm{~mm}, 1.2 \mathrm{~mm}, 1.4 \mathrm{~mm}$, $1.7 \mathrm{~mm}$, and $2.0 \mathrm{~mm}$ ) of the as-received samples, as-received moisture-equilibrated samples and saturated moisture-equilibrated samples (steps 1,2, and 3) were measured with the Shale Matrix Permeameter (SMP 200). The pressure decay curves for the as-received, as-received moisture-equilibrated and saturated moisture-equilibrated samples were assessed for matrix permeability as described in Cui et al. (2009) and Achang et al. (2017). After the permeability of the moistureequilibrated samples was measured, the samples were ovendried (Fig. 1a, steps 4 and 5) and the permeability again measured and compared with the as-received values.

\section{Results}

\subsection{Time required for moisture equilibration of as-received moisture-equilibrated and saturated moisture-equilibrated samples}

The time required for moisture equilibration of $15 \mathrm{~g}$ samples is $72 \mathrm{~h}$ (Fig. 2). The region where the best-fit line for the data appears to be more stable, in Fig. 2b, is the region where moisture change becomes negligible, indicating that moisture content had reached equilibrium at a relative humidity of $97 \%$. Samples actually begin to attain equilibrium after $48 \mathrm{~h}$; but because $48 \mathrm{~h}$ is at the boundary between steep moisture change and little moisture change, a value that was used for the entire study is $72 \mathrm{~h}$ for $15 \mathrm{~g}$ masses and $96 \mathrm{~h}$ for 75-80 g mass of crushed shale samples.

The initial moisture content of the as-received samples obtained from a depth of $4909 \mathrm{ft}$ (1496.26 m) was estimated to be $0.57 \%$. The moisture content in the as-received sample increased from $0.57 \%$ to $1.5 \%$ within $24 \mathrm{~h}$ of moisture equilibration and stayed relatively constant at $1.5 \%$ moisture content. The sample reached equilibrium by $48 \mathrm{~h}$, and the moisture content did not change significantly for the remainder of the 120-h equilibration period (Fig. 2a). The moisture content for the saturated moisture-equilibrated samples increased to $8-10 \%$ within $24 \mathrm{~h}$ (Fig. 2a). The moisture content of the saturated moisture-equilibrated samples, which were saturated for $3 \mathrm{~h}$ and $24 \mathrm{~h}$, reached equilibrium by $48 \mathrm{~h}$ and moisture content remained effectively constant at approximately $2.9 \%$ and $1.9 \%$ (Fig. 2b), respectively. Overall moisture content gained by as-received (unsaturated) moisture-equilibrated samples is $1.5 \%$ compared to $2.9 \%$ and $1.9 \%$ for saturated moisture-equilibrated samples (Fig. 2b).

\subsection{Variation in equilibrium moisture content versus permeability}

A plot of moisture content expressed as percent pore volume versus permeability for saturated moisture-equilibrated samples (Fig. 3a) and as-received moisture-equilibrated samples (Fig. 3b) shows a decreasing exponential relationship.
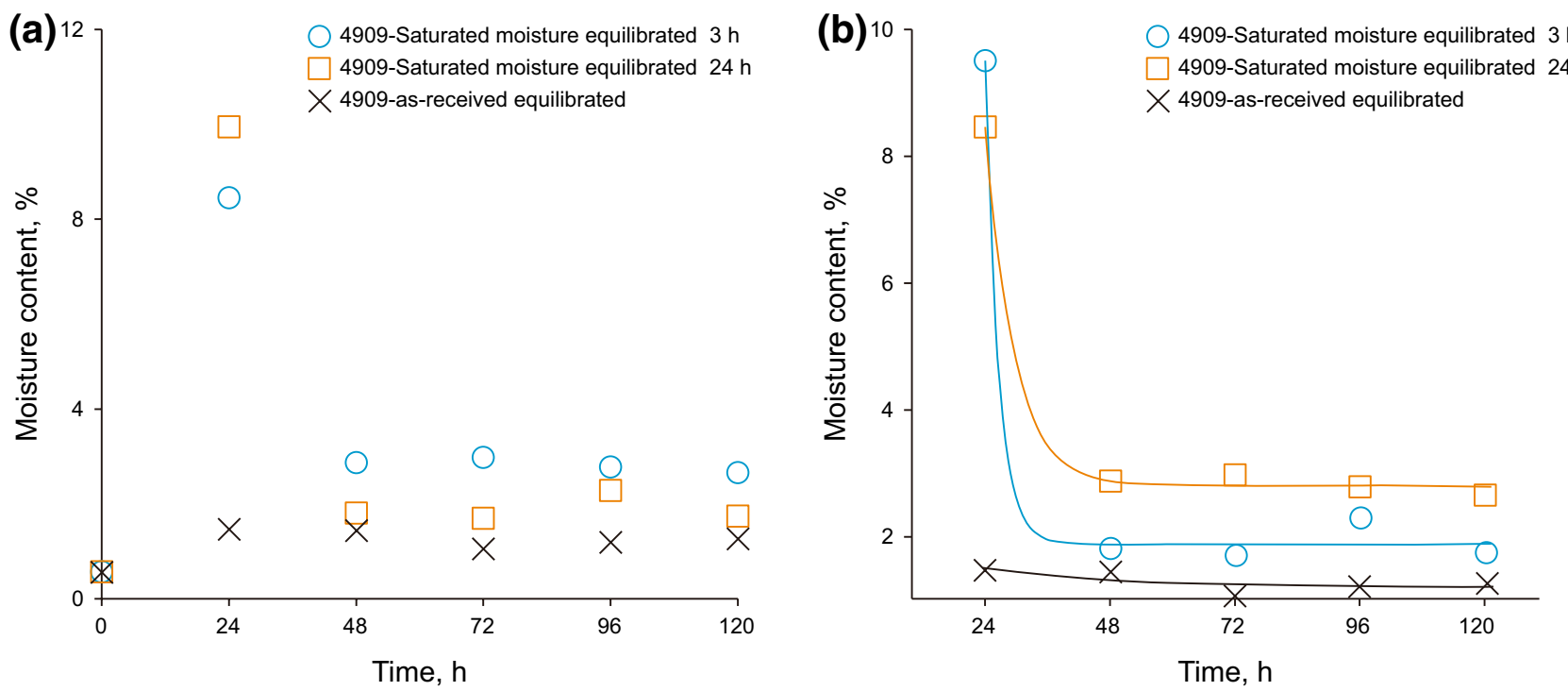

Fig. 2 a Time versus moisture gained and $\mathbf{b}$ time versus moisture content gained for saturated moisture-equilibrated samples for $3 \mathrm{~h}$ and $24 \mathrm{~h}$ and as-received (unsaturated) moisture-equilibrated samples from a depth of $4909 \mathrm{ft}$ (1496.3 m) 

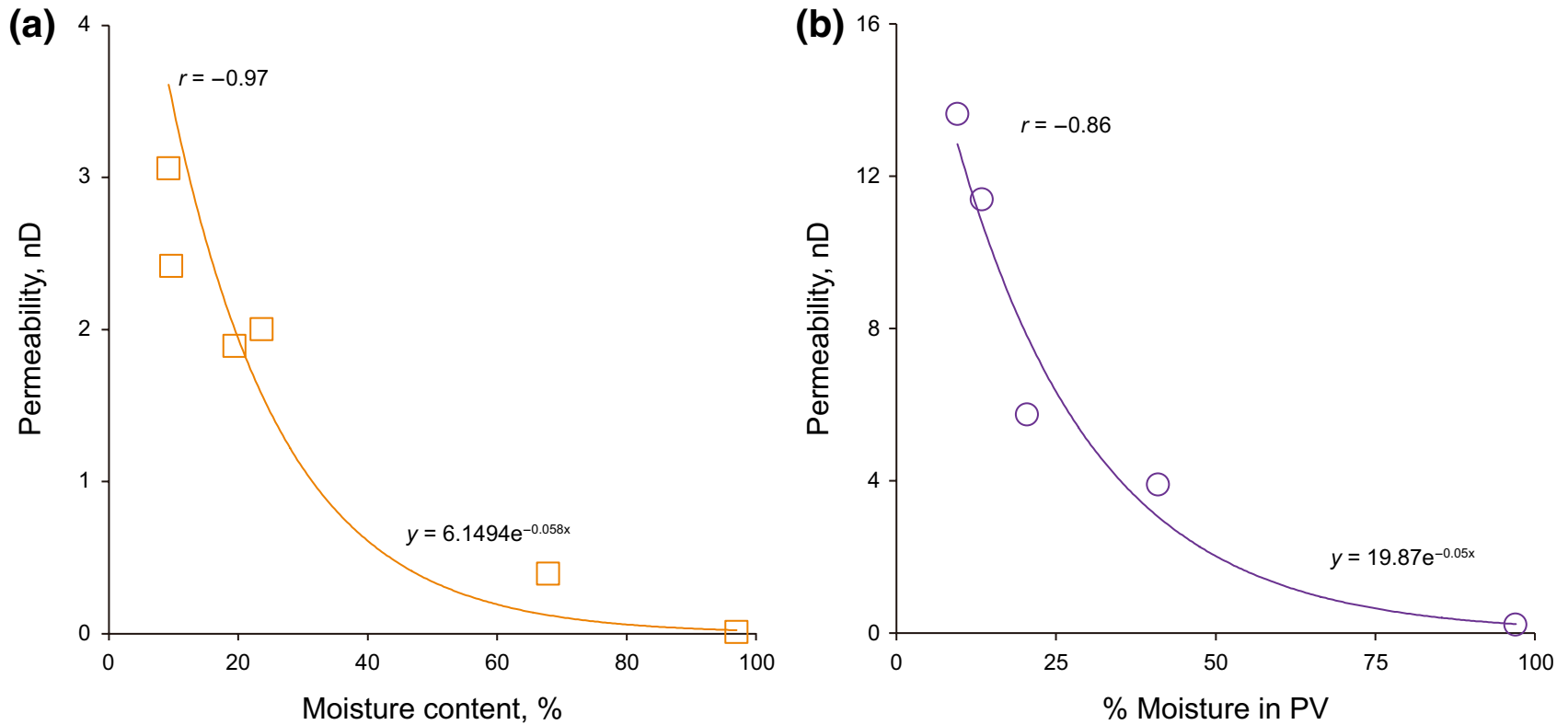

Fig. 3 Relationship between moisture content (\% pore volume) and permeability in a saturated moisture-equilibrated shale samples b asreceived (unsaturated) moisture-equilibrated shale samples. The sample particle size is $1.4 \mathrm{~mm}$ and is from a depth of $4909 \mathrm{ft}$ (1496.3 m)

Regression analysis indicates a negative correlation coefficient of -0.97 for saturated moisture-equilibrated samples and -0.86 for as-received (unsaturated) moisture-equilibrated samples (Fig. 3b). When the moisture content in the pore volume (PV) is approximately $97 \%$, permeability is only $-0.01 \mathrm{nD}$ for saturated moisture-equilibrated samples and $0.22 \mathrm{nD}$ for as-received moisture-equilibrated samples. Permeability increases with decreasing moisture from 0.01 to $3.2 \mathrm{nD}$ at a moisture content of $70 \%$ and increases exponentially to $3.0 \mathrm{nD}$ as equilibrium moisture content falls to about $10 \%$ of pore volume (Fig. 3a). Also, the permeability of the as-received (unsaturated) moisture-equilibrated samples is greater than that for the saturated moisture-equilibrated samples.

\subsection{Permeability measurements of as-received moisture-equilibrated and saturated moisture-equilibrated samples}

For as-received, saturated moisture-equilibrated and asreceived (unsaturated) moisture-equilibrated samples, permeability correlates positively with particle size (Fig. 4a, b). The as-received samples have higher permeability than the saturated moisture-equilibrated and as-received (unsaturated) moisture-equilibrated samples. For samples from a depth of $4907 \mathrm{ft}$ (1495.65 m), permeability ranges from $4.47 \mathrm{nD}$ to $171.9 \mathrm{nD}$ for as-received samples (Achang et al. 2017) and $0.5 \mathrm{nD}$ to $6.8 \mathrm{nD}$ for saturated moistureequilibrated samples. For samples from the depth $4909 \mathrm{ft}$ (1496.26 m), as-received permeability ranges from 1.65 to
$13.05 \mathrm{nD}$, as-received moisture-equilibrated sample permeabilities range from 0.15 to $5.3 \mathrm{nD}$, and the permeability of saturated moisture-equilibrated samples from 0.16 to $6.8 \mathrm{nD}$. Correlation coefficients of 0.96 and 0.97 were calculated for the saturated moisture-equilibrated samples at depths of $4907 \mathrm{ft}$ and $4909 \mathrm{ft}$, respectively, compared to 0.95 and 0.76 for the as-received samples of same depth in turn. The permeability of as-received samples from $4907 \mathrm{ft}$ is greater than that of the saturated moisture-equilibrated samples from that depth. The correlation coefficient of the as-received sample (0.76) is smaller than that of the as-received moisture-equilibrated samples (0.96) and saturated moisture-equilibrated samples (0.97) samples from $4909 \mathrm{ft}$ (Fig. 4b). Multiple runs to determine the permeability of samples after moisture equilibration resulted in greater repeatability than multiple runs for the as-received samples (Tables 1 and 2). For different particle sizes, the relative error of the permeability for as-received samples from $4907 \mathrm{ft}$ ranged from $3.0 \%$ to $23.0 \%$ and from $11 \%$ to $38 \%$ for saturated moisture-equilibrated samples (Fig. 5). For the samples taken from $4909 \mathrm{ft}$. depth, the relative error for as-received samples, saturated moisture-equilibrated and as-received moisture-equilibrated samples ranged from $5.7 \%$ to $30 \%, 3.4 \%$ to $24 \%$, and $7.4 \%$ to $18 \%$, respectively. Nevertheless, the results for particle size $0.71 \mathrm{~mm}$ and $1.18 \mathrm{~mm}$ have an exceptionally large error of $39 \%$ and $24 \%$

Figure 6 shows a plot of particle size versus permeability of as-received, as-received moisture-equilibrated and saturated moisture-equilibrated samples that were subsequently oven-dried. The results were plotted and compared with the 

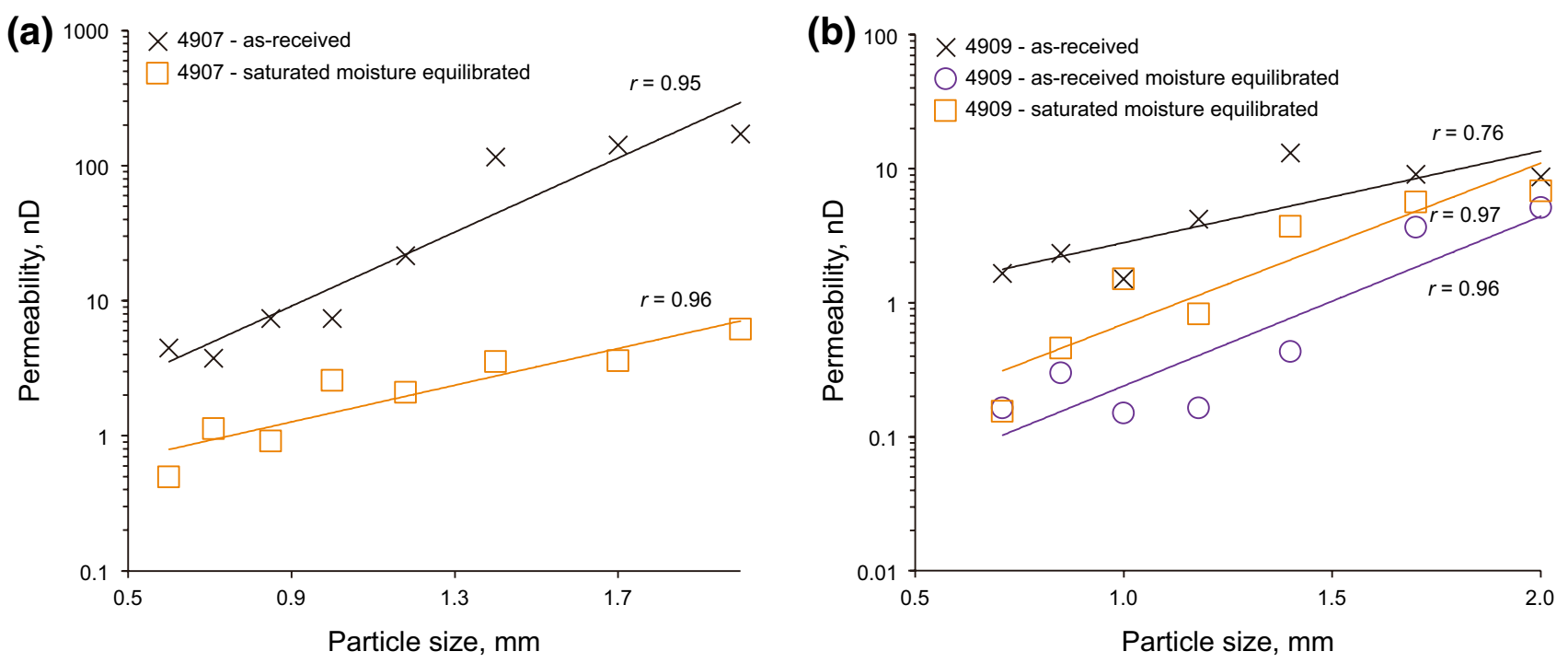

Fig. 4 Particle size versus permeability for as-received, as-received moisture-equilibrated, and saturated moisture-equilibrated samples from the Danker \#1-28 core a $4907 \mathrm{ft}$ (1495.65 m) and b $4909 \mathrm{ft}$ (1496.26 m)

permeability of the as-received samples. The correlation coefficients derived from the regression analysis of the ovendried samples are 0.95 (saturated moisture equilibrated) and 0.96 (as-received moisture equilibrated) in comparison with 0.76 for the as-received sample.

\section{Discussion}

\subsection{Variation in equilibrium moisture content expressed as percent pore volume and permeability}

The dominant clay minerals in the Danker \#1-28 core include chlorite, kaolinite, and illite which are non-expandable, and thus, wetting and drying samples had minimal impact on rock fabric. Moisture content is inversely exponentially proportional to permeability (Fig. 3). Thus, as the moisture-filled portion of the pore volume decreases, the permeability to gas increases exponentially in both saturated moisture-equilibrated and as-received moisture-equilibrated samples (Fig. 3a, b). The permeability for saturated moisture-equilibrated samples ranges from $0.1 \mathrm{nD}$ in samples, where moisture occupies approximately $97 \%$ of the pore volume, and $14 \mathrm{nD}$ in samples, where moisture occupies about $10 \%$ of the pore volume. Additional moisture, including some clay bound water, would be removed if the samples were heated to $140{ }^{\circ} \mathrm{C}$ and all structural-bound water would be removed if the samples were heated beyond $400{ }^{\circ} \mathrm{C}$ (Handwerger et al. 2011; Sondergeld et al. 2010), potentially increasing permeability further. Therefore, the smaller the $\%$ moisture content in the pore volume, the greater the permeability and vice versa.

\subsection{Moisture equilibration of as-received and saturated samples}

The results of as-received samples and saturated moistureequilibrated samples show that the Woodford Shale samples were moisture equilibrated to moisture contents between 1.9 and $2.0 \%$ (which is similar to values measured for other Devonian shale Formations (Chalmers et al. 2010). Saturating samples with water prior to moisture equilibration results in higher equilibrium moisture values than equilibrating from the as-received state (Fig. 2b). A period of $72 \mathrm{~h}$ is required to equilibrate samples of $15 \mathrm{~g}$. However, for samples of $50 \mathrm{~g}$ or larger, it takes $96 \mathrm{~h}$ for equilibrium moisturization. The increase in moisture content from $0.6 \%$ to $10.0 \%$ followed by a decrease to $2.9 \%$ and $1.9 \%$ in saturated moisture-equilibrated samples indicates a reversal of the humidity gradient between the samples and water on surfaces of the particles and the desiccator. Following wetting (saturation), the shale is effectively saturated with water and gradually releases the water to the atmosphere in the desiccator until the sample reaches equilibrium with the moisture at a relative humidity of $97 \%$ atmosphere in the desiccator. In the as-received samples, the moisture moves from the atmosphere of the desiccator into the sample and so the moisture content increases from $0.57 \%$ to $1.9 \%$ (Fig. 2a). The difference in the moisture content between saturated moisture-equilibrated and as-received moisture-equilibrated samples is because it is easier to remove water from the shale samples than by adding water due to capillary forces. 
Table 1 Particle size and permeability (exponential decay segment) measurements for as-received samples and saturated moisture-equilibrated samples from the Danker \#1-28 core at $4907 \mathrm{ft}$ (1495.65 m)

\begin{tabular}{|c|c|c|c|c|c|c|c|c|}
\hline \multirow{3}{*}{$\begin{array}{l}\text { Sample } 4907 \\
\text { Repeats }\end{array}$} & \multicolumn{8}{|c|}{ Permeability (nD) } \\
\hline & \multicolumn{2}{|l|}{$2.0 \mathrm{~mm}$} & \multicolumn{2}{|l|}{$1.7 \mathrm{~mm}$} & \multicolumn{2}{|l|}{$1.4 \mathrm{~mm}$} & \multicolumn{2}{|l|}{$1.2 \mathrm{~mm}$} \\
\hline & As-received & $\begin{array}{l}\text { Saturated mois- } \\
\text { ture equilibrated }\end{array}$ & As-received & $\begin{array}{l}\text { Saturated mois- } \\
\text { ture equilibrated }\end{array}$ & As-received & $\begin{array}{l}\text { Saturated mois- } \\
\text { ture equilibrated }\end{array}$ & As-received & $\begin{array}{l}\text { Saturated mois- } \\
\text { ture equilibrated }\end{array}$ \\
\hline 1 & 248.98 & 6.11 & 138.43 & 4.08 & 11.93 & 4.96 & 11.08 & 2.33 \\
\hline 2 & 133.37 & 6.07 & 192.16 & 3.38 & 10.36 & 3.19 & 37.09 & 2.00 \\
\hline 3 & 133.37 & 5.82 & 94.92 & 3.04 & 7.23 & 3.50 & 16.59 & 1.98 \\
\hline 4 & $\mathrm{a}^{\mathrm{a}}$ & 6.74 & I & 3.42 & 6.70 & 2.79 & I & 1.98 \\
\hline 5 & / & 6.16 & / & 4.13 & / & 3.27 & / & 2.18 \\
\hline Mean & 171.91 & 6.18 & 141.84 & 3.61 & 9.06 & 3.54 & 21.59 & 2.09 \\
\hline Std & 66.75 & 0.39 & 39.77 & 0.38 & 2.17 & 0.747 & 11.19 & 0.14 \\
\hline Mean of Std & 38.54 & 0.18 & 22.96 & 0.17 & 1.09 & 0.334 & 6.46 & 0.06 \\
\hline Rel error & $22.42 \%$ & $2.83 \%$ & $16.19 \%$ & $4.65 \%$ & $11.99 \%$ & $9.43 \%$ & $29.94 \%$ & $3.02 \%$ \\
\hline \multirow[t]{2}{*}{ Sample 4907} & \multicolumn{8}{|l|}{ Permeability } \\
\hline & \multicolumn{2}{|l|}{$1.0 \mathrm{~mm}$} & \multicolumn{2}{|l|}{$0.85 \mathrm{~mm}$} & \multicolumn{2}{|l|}{$0.71 \mathrm{~mm}$} & \multicolumn{2}{|l|}{$0.60 \mathrm{~mm}$} \\
\hline Repeats & As-received & $\begin{array}{l}\text { Saturated mois- } \\
\text { ture equilibrated }\end{array}$ & As-received & $\begin{array}{l}\text { Saturated mois- } \\
\text { ture equilibrated }\end{array}$ & As-received & $\begin{array}{l}\text { Saturated mois- } \\
\text { ture equilibrated }\end{array}$ & As-received & $\begin{array}{l}\text { Saturated mois- } \\
\text { ture equilibrated }\end{array}$ \\
\hline 1 & 7.98 & 2.88 & 3.23 & 0.56 & 2.59 & 1.14 & 2.34 & 0.55 \\
\hline 2 & 7.58 & 2.48 & 13.21 & 1.30 & 4.90 & 1.47 & 6.60 & 0.56 \\
\hline 3 & 6.62 & 2.40 & 4.18 & 0.89 & I & 2.01 & I & 0.38 \\
\hline 4 & & 3.27 & I & I & I & 0.47 & I & I \\
\hline 5 & I & I & I & I & I & 0.57 & I & I \\
\hline Mean & 7.81 & 2.58 & 6.87 & 0.92 & 3.75 & 1.13 & 4.47 & 0.50 \\
\hline $\mathrm{Std}^{\mathrm{b}}$ & 0.57 & 0.35 & 4.50 & 0.31 & 1.15 & 0.57 & 2.13 & 0.08 \\
\hline Mean of Std & 0.28 & 0.17 & 2.60 & 0.18 & 0.82 & 0.26 & 1.51 & 0.05 \\
\hline $\operatorname{Rel}^{c}$ error & $5.64 \%$ & $6.75 \%$ & $37.78 \%$ & $19.23 \%$ & $21.77 \%$ & $22.62 \%$ & $33.72 \%$ & $9.55 \%$ \\
\hline
\end{tabular}

${ }^{\text {a }}$ Means no data available

${ }^{\mathrm{b}}$ Std means standard deviation

${ }^{\mathrm{c}}$ Rel error means relative error

Bigourdan et al. (1997) made similar observations when photographic films and library books (organic materials) were exposed to different levels of relative humidity and moisture.

\subsection{Moisture-equilibrated samples and matrix permeability}

The permeability of as-received samples, saturated moisture-equilibrated samples, and as-received moisture-equilibrated samples increases with increasing particle size. The positive correlation between permeability and particle size was first observed by Cui et al. (2009), which they explained using a dual-porosity model. In this model, connected macropores and micropores are responsible for the increase in permeability with an increase in particle size. Achang et al. (2017) have made similar observations and suggested that the positive correlation results mainly from the presence of macropores, particularly in larger particle sizes and microfractures, which were observed in scanning electron microscopy images and in many cases appear to be a result of crushing the shale samples. The high correlation coefficient between permeability and particle size $(r=0.96$ and 0.97$)$ for moisture-equilibrated samples compared to 0.76 for as-received samples (Fig. 4a, b) suggests that moisture equilibration improves the robustness of pressure decay permeability measurements in crushed shale samples. Furthermore, permeability measurements are repeatable for moisture-equilibrated samples compared to samples that were not equilibrated (Tables 1 and 2). The relative errors observed for the largest particles sizes $>1.0 \mathrm{~mm}$ are more consistent compared to those observed for the particle sizes $<1 \mathrm{~mm}$, where scattering is dominant. Thus, more complete moisture equilibration of larger particles. Clarkson et al. (2011) showed that crushed particles lose moisture faster than core plugs, and so it follows that smaller crushed 
Table 2 Particle size and permeability measurements for as-received, saturated moisture-equilibrated, and as-received moisture-equilibrated samples from the Danker \#1-28 core at $4909 \mathrm{ft}$ (1496.26 m)

\begin{tabular}{|c|c|c|c|c|c|c|}
\hline \multirow{3}{*}{$\begin{array}{l}\text { Sample } 4909 \\
\text { Repeats }\end{array}$} & \multicolumn{6}{|c|}{ Permeability (nD) } \\
\hline & \multicolumn{3}{|l|}{$2.0 \mathrm{~mm}$} & \multicolumn{3}{|l|}{$1.7 \mathrm{~mm}$} \\
\hline & As-received & $\begin{array}{l}\text { As-received moisture } \\
\text { equilibrated }\end{array}$ & $\begin{array}{l}\text { Saturated moisture } \\
\text { equilibrated }\end{array}$ & As-received & $\begin{array}{l}\text { As-received moisture } \\
\text { equilibrated }\end{array}$ & $\begin{array}{l}\text { Saturated mois- } \\
\text { ture equilibrated }\end{array}$ \\
\hline 1 & 7.15 & 4.47 & 7.46 & 11.93 & 3.59 & 5.42 \\
\hline 2 & 11.00 & 6.89 & 8.48 & 10.36 & 3.61 & 4.64 \\
\hline 3 & 7.86 & 4.96 & 5.41 & 7.23 & 4.28 & 5.53 \\
\hline 4 & & 4.78 & 5.85 & 6.70 & 3.12 & 6.95 \\
\hline 5 & & 4.55 & / & / & & / \\
\hline Mean & 8.67 & 5.13 & 6.80 & 9.06 & 3.65 & 5.64 \\
\hline Std & 2.048 & 1.004 & 1.43 & 2.17 & 0.414 & 0.83 \\
\hline Mean of Std & 1.182 & 0.449 & 0.71 & 1.09 & 0.207 & 0.42 \\
\hline Rel error & $13.64 \%$ & $8.75 \%$ & $10.48 \%$ & $11.99 \%$ & $5.68 \%$ & $7.40 \%$ \\
\hline \multirow[t]{2}{*}{ Sample 4909} & \multicolumn{6}{|c|}{ Permeability (nD) } \\
\hline & \multicolumn{3}{|l|}{$1.4 \mathrm{~mm}$} & \multicolumn{3}{|l|}{$1.2 \mathrm{~mm}$} \\
\hline Repeats & As-received & $\begin{array}{l}\text { As-received moisture } \\
\text { equilibrated }\end{array}$ & $\begin{array}{l}\text { Saturated moisture } \\
\text { equilibrated }\end{array}$ & As-received & $\begin{array}{l}\text { As-received moisture } \\
\text { equilibrated }\end{array}$ & $\begin{array}{l}\text { Saturated mois- } \\
\text { ture equilibrated }\end{array}$ \\
\hline 1 & 12.01 & 0.59 & 4.71 & 4.88 & 0.20 & 0.93 \\
\hline 2 & 14.09 & 0.37 & 4.40 & 3.53 & 0.04 & 1.14 \\
\hline 3 & I & 0.35 & 3.26 & I & 0.17 & 0.85 \\
\hline 4 & / & 0.38 & 3.07 & / & 0.25 & 0.78 \\
\hline 5 & / & 0.46 & 3.07 & / & & 0.42 \\
\hline Mean & 13.05 & 0.43 & 3.70 & 4.21 & 0.16 & 0.82 \\
\hline Std & 1.04 & 0.086 & 0.71 & 0.67 & 0.080 & 0.24 \\
\hline Mean of Std & 0.74 & 0.038 & 0.32 & 0.48 & 0.040 & 0.11 \\
\hline Rel error & $5.64 \%$ & $8.93 \%$ & $8.52 \%$ & $11.32 \%$ & $24.34 \%$ & $12.81 \%$ \\
\hline \multirow[t]{2}{*}{ Sample 4909} & \multicolumn{6}{|c|}{ Permeability (nD) } \\
\hline & \multicolumn{3}{|l|}{$1.0 \mathrm{~mm}$} & \multicolumn{3}{|l|}{$0.85 \mathrm{~mm}$} \\
\hline Repeats & As-received & $\begin{array}{l}\text { As-received moisture } \\
\text { equilibrated }\end{array}$ & $\begin{array}{l}\text { Saturated moisture } \\
\text { equilibrated }\end{array}$ & As-received & $\begin{array}{l}\text { As-received moisture } \\
\text { equilibrated }\end{array}$ & $\begin{array}{l}\text { Saturated mois- } \\
\text { ture equilibrated }\end{array}$ \\
\hline 1 & 1.08 & 0.14 & 1.08 & 2.56 & 0.29 & 0.24 \\
\hline 2 & 2.15 & 0.15 & 2.15 & 2.09 & 0.29 & 0.79 \\
\hline 3 & 1.64 & 0.17 & 1.64 & & 0.32 & 0.46 \\
\hline 4 & 0.98 & 0.15 & 0.98 & & 0.30 & 0.41 \\
\hline 5 & 1.64 & & 1.64 & & & 0.39 \\
\hline Mean & 1.50 & 0.15 & 1.50 & 2.33 & 0.30 & 0.46 \\
\hline Std & 0.47 & 0.010 & 0.42 & 0.24 & 0.02 & 0.18 \\
\hline Mean of Std & 0.21 & 0.005 & 0.19 & 0.17 & 0.01 & 0.08 \\
\hline Rel error & $13.98 \%$ & $3.37 \%$ & $12.68 \%$ & $7.19 \%$ & $2.57 \%$ & $17.76 \%$ \\
\hline \multirow[t]{2}{*}{ Sample 4909} & \multicolumn{6}{|c|}{ Permeability (nD) } \\
\hline & \multicolumn{3}{|l|}{$0.71 \mathrm{~mm}$} & \multicolumn{3}{|l|}{$0.60 \mathrm{~mm}$} \\
\hline Repeats & As-received & $\begin{array}{l}\text { As-received moisture } \\
\text { equilibrated }\end{array}$ & $\begin{array}{l}\text { Saturated moisture } \\
\text { equilibrated }\end{array}$ & As-received & $\begin{array}{l}\text { As-received moisture } \\
\text { equilibrated }\end{array}$ & $\begin{array}{l}\text { Saturated mois- } \\
\text { ture equilibrated }\end{array}$ \\
\hline 1 & 2.16 & 0.15 & 0.01 & 0.28 & 0.09 & / \\
\hline 2 & 1.09 & 0.16 & 0.05 & 1.00 & 0.05 & / \\
\hline 3 & 2.21 & 0.19 & 0.37 & 1.41 & 0.07 & I \\
\hline
\end{tabular}


Table 2 (continued)

\begin{tabular}{|c|c|c|c|c|c|c|}
\hline \multirow[t]{3}{*}{ Sample 4909} & \multicolumn{6}{|c|}{ Permeability (nD) } \\
\hline & \multicolumn{3}{|l|}{$0.71 \mathrm{~mm}$} & \multicolumn{3}{|l|}{$0.60 \mathrm{~mm}$} \\
\hline & As-received & $\begin{array}{l}\text { As-received moisture } \\
\text { equilibrated }\end{array}$ & $\begin{array}{l}\text { Saturated moisture } \\
\text { equilibrated }\end{array}$ & As-received & $\begin{array}{l}\text { As-received moisture } \\
\text { equilibrated }\end{array}$ & $\begin{array}{l}\text { Saturated mois- } \\
\text { ture equilibrated }\end{array}$ \\
\hline 4 & l & 0.16 & 0.08 & I & 0.06 & l \\
\hline 5 & / & 0.16 & 0.26 & l & 0.09 & l \\
\hline Mean & 1.65 & 0.16 & 0.15 & 0.89 & 0.07 & l \\
\hline Std & 0.51 & 0.01 & 0.14 & 0.47 & 0.02 & l \\
\hline Mean of Std & 0.30 & 0.01 & 0.06 & 0.27 & 0.01 & l \\
\hline Rel error & $17.98 \%$ & $3.65 \%$ & $39.40 \%$ & $30.13 \%$ & $11.95 \%$ & I \\
\hline
\end{tabular}

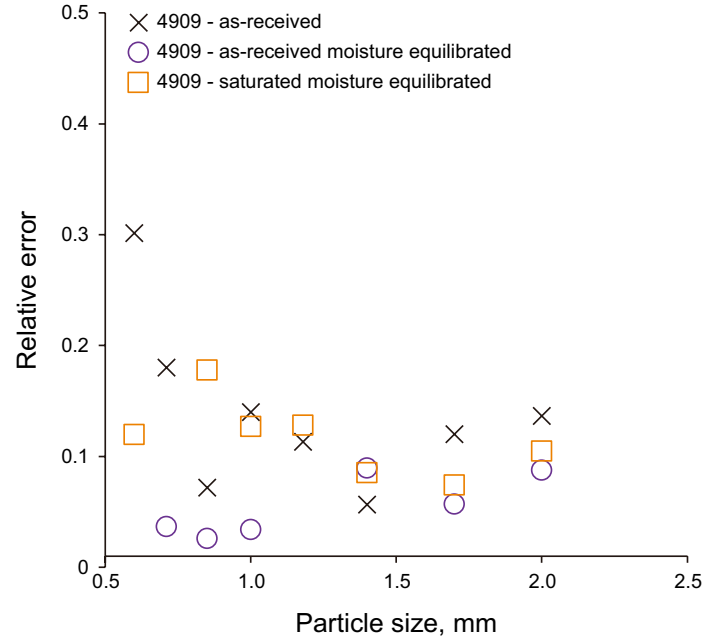

Fig. 5 Relative error in permeability of as-received, as-received moisture equilibrated, and saturated moisture-equilibrated samples. Most of the scattering in the error is below the $1.4 \mathrm{~mm}$ particle size range. All samples taken from $4909 \mathrm{ft}$ (1496.3 m)

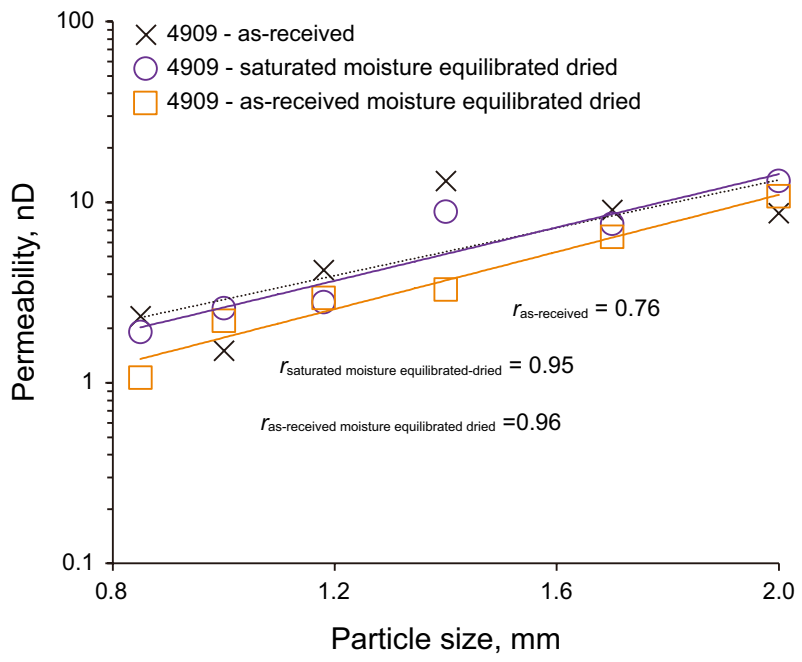

Fig. 6 Particle size vs. permeability of samples that were oven-dried for $1.5 \mathrm{~h}$ after moisture equilibration from $4909 \mathrm{ft}(1496.3 \mathrm{~m})$ particles would lose moisture faster than larger crushed particles. We propose that the scattering observed in the relative error (Fig. 5) for particles sizes $<1.0 \mathrm{~mm}$ could result from lower effectiveness in equilibration of moisture particle sizes $<1.0 \mathrm{~mm}$, making them not ideal for moisture equilibration and permeability determination. Since the permeability of the equilibrated samples is lower than that of the as-received samples (Fig. 6), we suggest that the moisture equilibration process homogenizes moisture in pores within the shale sample. Additionally, when all the saturated samples were oven-dried and the estimated permeability compared with those of the as-received samples, the correlation coefficient of the moisture-equilibrated and dried samples was greater than those of the as-received samples (Fig. 6). Higher correlation coefficients between particle size and permeability (Fig. 6) of moisture-equilibrated samples and saturated moisture-equilibrated samples that were dried again highlight the importance of applying a standard procedure (ASTM, D1412-07) for moisture equilibration to improve the consistency and predictability of pressure decay permeability determinations.

An important limitation of moisture equilibration is that it probably does not restore shale to its native state, particularly in samples where hydrocarbons have volatized. However, moisture equilibration reduces capillarity and effective permeability artifacts related to moisture loss when determining matrix permeability. Moreover, some moisture is lost during the transfer of samples from the desiccator to the permeameter (average of $0.068 \mathrm{~g}$ of moisture is lost in $3 \mathrm{~h}$ from samples of particle size $1.4 \mathrm{~mm}$ ), which is equivalent to $0.09 \%$ of the moisture content by pore volume. The $0.09 \%$ error in moisture content is negligible.

\section{Conclusions}

Moisture content is inversely related to permeability in shale. Equilibrating shale samples to equilibrium moisture content results in more accurate and repeatable measurements 
and in greater predictability of basic relationships, such as the relationship between permeability and particle size. The particle size-permeability relationship of moisture-equilibrated samples increases with increasing particle size, and moisture-equilibrated samples have better correlation coefficients compared to as-received samples, indicating that moisture equilibration improves pressure decay permeability measurements in crushed shale samples. Therefore, moisture equilibration is recommended as a standard way for preparing shale samples for permeability measurements.

Moisture equilibration can be performed to help restore moisture lost during sample storage and can be performed on unsaturated (as-received) samples or water-saturated samples. The Woodford Shale samples studied in this research have unexpandable clays, and so quantitative results were obtained using as-received and saturated samples. The duration for moisture equilibration in the shale samples studied is $72 \mathrm{~h}$ for samples equal to or smaller than $15 \mathrm{~g}$ and $96 \mathrm{~h}$ for samples of $75 \mathrm{~g}$ to $100 \mathrm{~g}$. All samples gained moisture during equilibration, and saturated samples retained more moisture at equilibrium than unsaturated (as-received) samples. Even though moisture equilibration does not restore the shale sample to its original moisture content, particularly in samples where hydrocarbons had been present, equilibrium moisturization helps normalize analyses by compensating for moisture loss post-core retrieval, transport, and storage.

Acknowledgements This study was supported in part by Grants-inAid Fund from the American Association of Petroleum Geologists and National Association of Black Geoscientists. We thank J. Puckette for providing access to the Danker \#1-28 core. The authors thank six anonymous reviewers for comments and suggestions that helped improve the quality of this manuscript.

Open Access This article is distributed under the terms of the Creative Commons Attribution 4.0 International License (http://creativeco mmons.org/licenses/by/4.0/), which permits unrestricted use, distribution, and reproduction in any medium, provided you give appropriate credit to the original author(s) and the source, provide a link to the Creative Commons license, and indicate if changes were made.

\section{References}

Achang M, Pashin J, Cui X. The influence of particle size, microfractures, and pressure decay on measuring the permeability of crushed shale samples. Int J Coal Geol. 2017;183:174-87.

ASTM D1412-07 Standard test method for equilibrium moisture of coal at 96 to 97 percent relative humidity and $30^{\circ} \mathrm{C}$, ASTM International, West Conshohocken, PA. 2007. https://doi.org/10.1520/ D1412-07.

Bigourdan JL, Adelstein P.Z, Reilly J.M. Moisture and temperature equilibration: behaviour and practical significance in photographic film preservation. In La conservation: une science en évolution. Bilan et perspectives. Actes des troisièmes journées internationales d'études de l'ARSAG, Paris, 21-25 avril 1997; pp. 154-164.

Chalmers GR, Bustin MR. The effects and distribution of moisture in gas shale reservoir systems. AAPG search and discovery. 2010; 80113.

Chenevert ME, Amanullah MD. A novel laboratory technique to determine the saturation status of shale. In: International symposium of the society of core analyses. 1997; SCA-9728.

Clarkson CR, Jensen JL, Blasingame T. Reservoir engineering for unconventional reservoirs: what do we have to consider? Soc Pet Eng, paper SPE 145080. 2011. https://doi.org/10.2118/14508 0 -ms.

Cui X, Bustin AMM, Bustin RM. Measurements of gas permeability and diffusivity of tight reservoir rocks: different approaches and their applications. Geofluids. 2009;9(3):208-23.

Handwerger DA, John K, Vaughn K. Improved petrophysical core measurements on tight shale reservoirs using retort and crushed samples. Soc Pet Eng, paper SPE. 2011; 147456. https://doi. org/10.2118/147456-ms.

Ingram RL. Fissility of mudrocks. Geol Soc Am Bull. 1953;64:869-78.

Loucks RG, Reed RM, Stephen CR, Ursula H. Spectrum of pore types and networks in mudrocks and a descriptive classification for matrix-related mudrock pores. AAPG Bull. 2012;96(6):1071-98.

Morris KA, Shepperd CM. The role of clay minerals in influencing porosity and permeability characteristics in the Bridport Sands of Wytch Farm. Dorset Clay Miner. 1982;17(1):41-54.

Sondergeld CH, Kent EN, Joseph TC, Morgan CR., and Chandra SR. Petrophysical considerations in evaluating and producing shale gas resources. Paper presented at the SPE unconventional gas conference, Pittsburgh, Pennsylvania, USA. 2010; 23-25 February (Reprint). SPE-131768. 